\title{
S100Z Gene
}

National Cancer Institute

\section{Source}

National Cancer Institute. S100Z Gene. NCI Thesaurus. Code C113558.

This gene plays a role in calcium ion binding. 